\title{
後頸部に発生した平滑筋腫例
}

\author{
武田広 誠

\section{A Case of Leiomyoma in the Posterior Neck}

\author{
Kousei Takeda \\ (Sendai Hospital National Defense Agency)
}

\begin{abstract}
Leiomyoma is a benign tumor of smooth muscle origin that is most commonly found in the uterus, gastrointestinal tract, and skin. It is rarely found in the head and neck area, especially in the skeletal muscles of the neck. A 21-year-old man complained of a painless mass on the right side of the posterior neck for one month. The tumor was removed surgically, and histopathological examination revealed a vascular leiomyoma. The postoperative course was uneventful, and no sign of recurrence has been noted 6 months after the operation.
\end{abstract}

Key words : leiomyoma, posterior neck, head and neck

はじめに

平滑筋腫は，子宮，消化管系でしばしばみられるが， 頭頸部領域に原発するものは比較的まれである。なかで も顔面，鼻腔，口唇を含めた頭部ではしばしば報告がみ られるが，食道や喉頭などの管腔蔵器を除いた頸部に限 れば，報告はきわめて少ない。今回，後頸部（僧帽筋下） に生じた平滑筋腫の一症例を経験したので, 若干の文献 的考察を加光て報告する.

\section{症例}

患者: 21歳, 男性.

主訴 : 右後頸部の腫瘤.

既往歴，家族歴：特記すべきことなし.

現病歴 : 1997年12月下旬頃, 右後頸部の腫瘤に気づい た. 徐々に大きくなってきたため1998年 1 月16日，当院 耳鼻咽喉科を受診した。

現症 : 右後頸部で僧帽筋前縁より後方に, $42 \times 30 \mathrm{~mm}$ 大の腫瘤を触知した。境界は明瞭, 可動性は良好で, 自 発痛, 压痛を認めなかった。他に耳鼻咽喉科領域の異常 所見は認められず，また血液，尿，心電図，胸部X線等 の諸検査で異常を認めなかった。
CT 所見 : 右僧帽笳と肩甲挙筋の間に, 辺縁が整で内 部が筋組織よりやや低吸収な腫瘤を認めた(図 $1 \mathrm{a})$. こ の腫瘤は, ほ注均一に中等度の造影剤増強効果を示した (図 $1 \mathrm{~b}$ ).

経過：非上皮性腫瘍の術前診断で，1月22日全身麻酔 下で摘出術を行った。体位は側臥位で, 皮切は腫瘤の直 上に皮膚割線に沿い横切開を行った．腫瘤は僧帽筋下に あり，小血管に富んでいたが周囲組織との癒着はほとん ぞみられず，被膜を含めて全摘出できた。途中，腫瘤と 連続する神経と思われる組織は認められなかった. 摘出 された腫瘤は， $2.5 \times 2.0 \times 1.5 \mathrm{~cm}$ の大きさで割面は充 実性であった(図 2 )。術後経過は順調で半年余りを経過 した現在に打いても再発は認められていない.

病理組織所見 : HE 染色では, 紡錘形の細胞が束状配 列を示しつつ増殖しているのが認められる(図 3 ). 所々 変性を伴い, 核/細胞質や細胞密度が比較的高い腫瘍だ が分裂像はほとんどみられない。免疫染色の結果では, ビメンチン陽性，デスミン陽性， $\alpha$-smooth muscle actin 陽性（図 4), S-100 陰性（図 5 ）, CD68陰性であった. 以上より, 平滑筋への分化傾向を有した腫瘍, すなわち 平滑筋腫と診断した. 


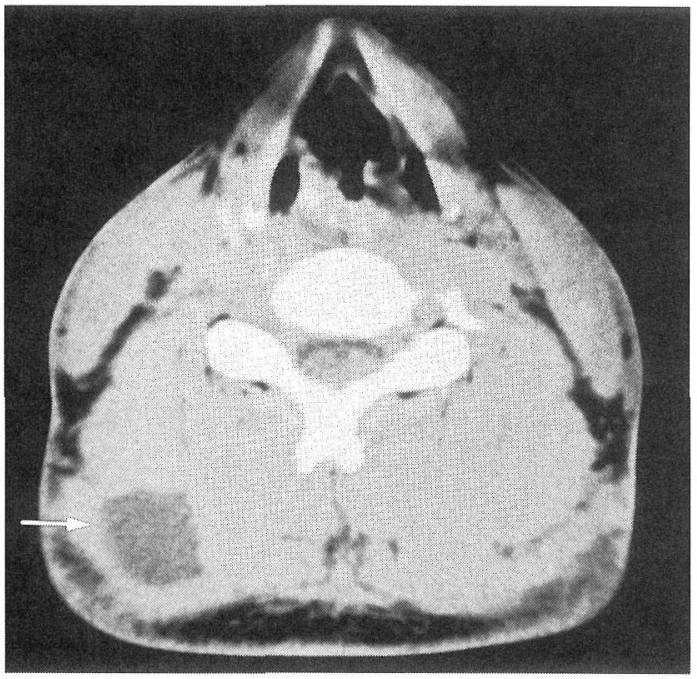

(a)

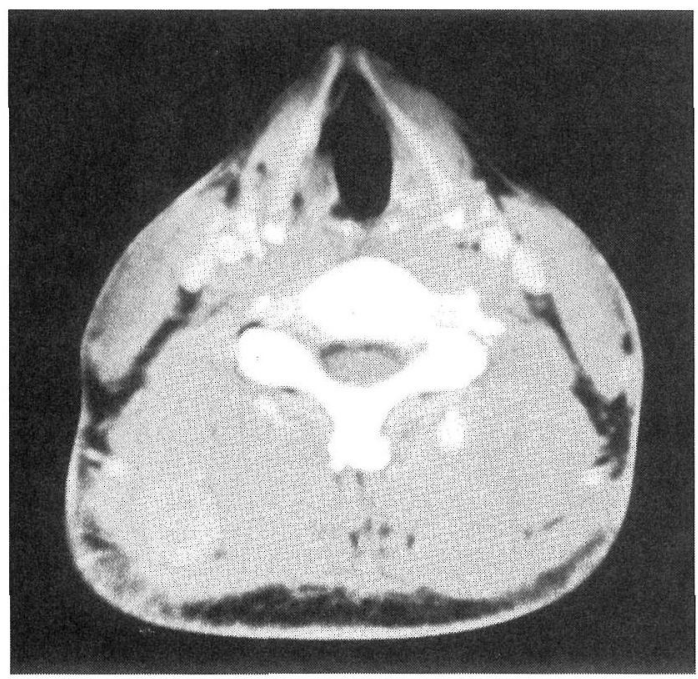

(b)

図 1 頸部 CT 所見

（a）造影前：右僧帽筋と肩甲挙筋の間に，筋組織より やや低吸收な腫瘤 $(\hookrightarrow)$ を認める.

（b）造影後：腫瘤は中等度の造影剤増強効果を示す.

\section{考察}

平滑筋腫は, WHO の軟部組織腫瘍国際分類 11 では, (1) leiomyoma, (2)angiomyoma (vascular leiomyoma), (3) epithelioid leiomyoma (bizarre leiomyoma, leioblastoma), の3 つに分類されている. また, AFIP (Armed Forces Institute of Pathology) の軟部組織腫瘍の項2) で, 特に平滑筋の豊富でない組織から発生する平滑筋腫を,

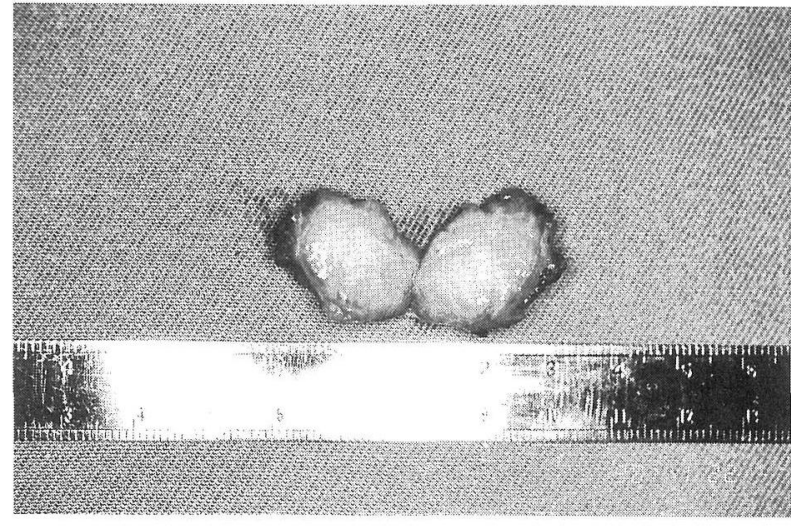

図 2 摘出標本

内部均一で充実性である。

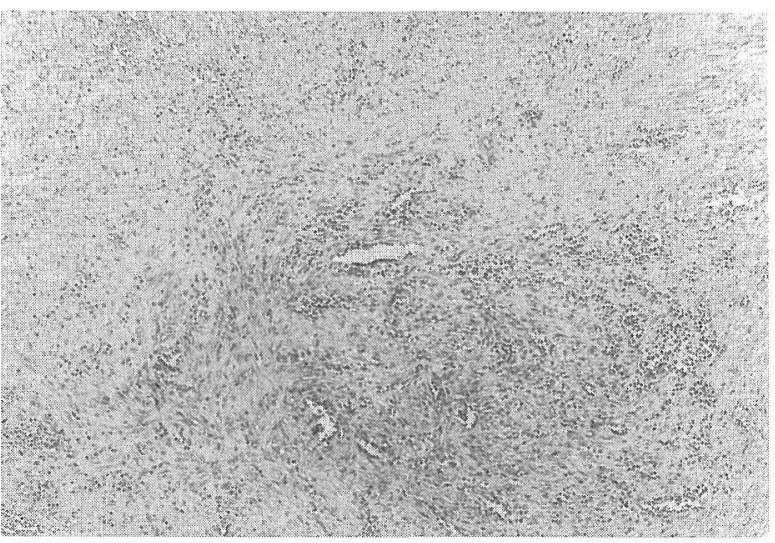

図 3 病理組織所見(1) (HE 染色, × 40) 紡錘形の細胞が束状配列を示しつつ増殖している。

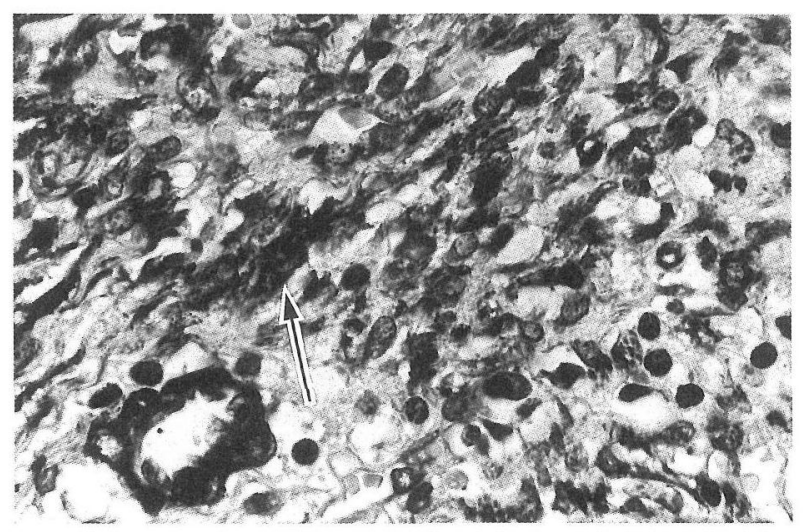

図 4 病理組織所見(2) $(\alpha$-SMA 染色, $\times 400)$

陽性所見で，(一)は陽性細胞の一部を示す。また血管 の平滑筋も染色されている。 


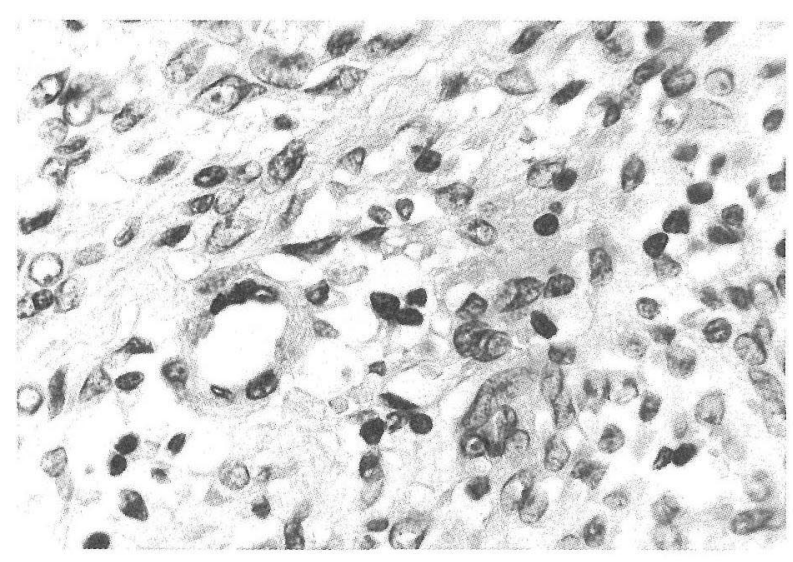

図 5 病理組織所見(3)(S-100 染色， × 400) 㓌性所見を示す.

(1) superficial leiomyoma, (2)vascular leiomyoma, (3) bizarre leiomyoma (leiomyoblastoma; epithelioid leiomyoma)の 3 つに分類している.このうち(1)は皮膚の立 毛筋由来, (2)は血管平滑筋由来, (3)は胃や十二指腸, 後 腹膜や縱隔の軟部組織に認められるまれな腫瘍であると している. 本来平滑筋組織の少ない頭頸部領域に和いて の平滑筋腫の由来は，皮膚の立毛筋か血管平滑筋々考兄 られるが，今回経験した症例は立毛筋のない深部より発 生していたことや，血管がやや豊富な部分もあることよ り，血管平滑筋由来であると思われた。

頭頸部領域の平滑筋腫は，森本 ${ }^{3)}$ の報告では血管筋腫 241例中, 顔面, 鼻腔, 口唇などを含めた頭部が22例(9.2 \%)で，頸部には全くみられなかったという．Hachisuga ら $\left.{ }^{4}\right)$ の報告では，血管筋腫562例中，頭部は48例 (8.5 \%)で，そのうち喉頭に1例みられたという。他に，喉 頭には20例の報告5)があり，また顔面，鼻腔，口唇など の頭部例は散見されるが，管腔臓器を除いた頸部に拉け る発生例は，頸部原発と考光られる平滑筋腫が12年後に 平滑筋肉腫として再発した報告6)の他は, 渉猟した限り では無かった。特に今回経験した症例のように，骨格筋 の間に発生したものはきわめてまれであると思われる。

平滑筋腫を術前に診断することは難しく，多くの場合 血管腫, 線維腫, 神経触腫などと診断されていることが 多(317)。 また，平滑筋由来の腫瘍を疑っても， $2.5 \mathrm{~cm}$ を越光る場合は悪性も考慮しなければいけないといわれ ている7). 今回経験した症例は, 骨格筋の間に発生して いたこともあり，平滑筋腫は術前の鑑別診断としては特
に考慮していなかった。ただし，比較的短期間で増大傾 向を示していたことょり, 悪性腫瘍の可能性は十分念頭 に和き治療に臨んだ。

平滑筋腫の確定診断には, 免疫染色が有用である.デ スミンの免疫染色は, 腫瘍の筋組織由来を証明するのに 有効とみなされている8). またアクチン, 特に $\alpha$-smooth muscle actin は平滑筋に対する特異性をもって拉り，心 筋や横紋筋には存在しないとされる8)。 また, 神経系腫 瘍の否定のためには，S-100 蛋白の免疫染色が有用であ る778)。ささら今回は神経系腫瘍や骨髄系の腫瘍でない ことを確認するために，CD68 染色も用いた8899.

治療は他の良性腫瘍と同様に外科的摘出のみである. これまでの報告例は, 単純摘出のみで再発はなく経過良 好なものが多いが，不完全な摘出で再発した症例5) や， 初回手術で平滑筋腫と診断されたが，12年後に平滑筋肉 腫として再発し死亡した症例6) 飞報告されて抒り, 今回 経験した症例も引き続き経過観察をする予定である.

\section{まとめ}

後頸部(僧帽筋之肩甲挙筋の間) に発生した平滑筋腫の 一例を経験したので，若干の文献的考察を加えて報告し た.

稿を終光るにあたり，訩療にご協力をいただきました，自衛 隊仙台病院整形外科(現自衛隊中央病院) 橋本道夫先生, 自衛隊 仙台病院皮膚科, 前嶋啓孝先生飞深謝致し未す。

\section{参考文献}

1) Enzinger FM, Latters R and Torlori H : Histological typing of soft tissue tumors. Internal Histological Classification of Tumors NO. 3 (ed by Enzinger FM). pp 30 31, WHO, Geneva, 1969.

2) Stout AP and Latters R: Tumor of the soft tissues. Atlas of Tumor Pathology (ed by Stout AP and Latters R). pp 58 63, AFIP, Washington D.C., 1966.

3 ) 森本典夫 : 血管筋腫 (血管性平滑筋腫)の臨床病理学的研究. 鹿大医誌 $24: 663 \sim 688,1973$.

4) Hachisuga T, Hashimoto $\mathrm{H}$ and Enjoji $\mathrm{M}$ : Angioleiomyoma; a clinicopathologic reappraisal of 562 cases. Cancer $54: 126 \sim 130,1984$.

5 ）鎌田利彦, 小川克二, 井口芳明, 他 : 喉頭に発生した血管 平滑筋種の 1 例. 日耳鼻 $98: 1119 \sim 1124,1995$.

6) Botting AJ, Soule EH and Brown AJ : Smooth muscle tumors in children. Cancer $18: 711 \sim 720,1965$. 
7 ）渡辺慶一, 中根一穂, 長村善之, 他 : 病理診断への応用. 酵素抗体法 (渡辺慶一編). pp 189 216, 学際企画, 東京, 1985.

8 ) Enzinger FM : Benign tumors of smooth muscle. Soft Tissue Tumors, 3rd ed (ed by Enzinger FM and Weiss SW). pp 467 490, CV Mosby, St. Louis, 1995.

9 ) Kipps TJ : The cluster of differentiation (CD) antigens.
Williams Hematology, 5th ed (ed by Beutler E). pp 113 〜 140, McGraw-Hill, New York, 1995.

$\left.\begin{array}{l}\text { 原稿受付 : 平成 } 10 \text { 年 } 9 \text { 月 } 14 \text { 日 } \\ \text { 原稿採択 : 平成 } 10 \text { 年 } 12 \text { 月 } 16 \text { 日 } \\ \text { 別刷請求先 : 武田広誠 } \\ \text { 个983-0041 仙台市宮城野区南目館 } 1-1 \\ \text { 自衛隊仙台病院耳鼻咽喉科 }\end{array}\right)$

